\title{
Construction sector's analysis in the supply and demand of residential buildings around the business management of Stakeholders
}

\author{
Análisis de la oferta y demanda en el sector de construcción de edificaciones \\ residenciales alrededor de la gestión empresarial en los Grupos de Interés
}

\section{Análise do setor da construção na oferta e demanda de edifícios residenciais em torno da gestão empresarial de Stakeholders}

\author{
Carlos-Gabriel Hernández-Carrillo ${ }^{10}$ \\ Jorge-Andrés Sarmiento-Rojas ${ }^{2}$ \\ Juan-Sebastián González-Sanabria ${ }^{3}$ (D)
}

Received: december 2020

Accepted: march 2021

How to cite: Hernández-Carrillo, C. G., Sarmiento-Rojas, S. R. y González-Sanabria, J. S. (2021). Construction sector's analysis in the supply and demand of residential buildings around the business management of Stakeholders. Revista Científica, 41(2), 213-224.

https://doi.org/10.14483/23448350.17549

\begin{abstract}
The global market was immersed in an environment of economic and political uncertainty, where trade and industrial production showed signs of marked weakness. However, in developing countries like Colombia, with a moderate expected economic growth, attributed to the implementation of strategies aimed at creating jobs, building public infrastructure and services to meet the needs of their rapidly expanding and urbanizing populations. Consequently, this research analyzed the external phenomena that have impacted the Colombian economy on the construction sector's housing supply and demand behavior. All the above, through the analysis of economic indicators, public policies, and stakeholder management around the use of tools, approaches, and methodologies established by different standards in project
\end{abstract}

management and the analysis of a business sample located in the city of Tunja. As mentioned above, it allowed the establishment of susceptibility to external economic phenomena and government policies in the construction sector. Those would enable the increased demand and boost other areas of the economy through stakeholders' effect in the supply and business capacities concerning its management, recognizing the expectations in the formulation and elaboration of projects in the current context. Nevertheless, companies related to the construction sector do not have adequate tools and personnel for this integral development, allowing them to identify factors when evaluating stakeholder management's business capacities, contributing to generating new methodologies and instruments that enable increasing construction projects' success.

1. M. Sc. (c) Universidad Pedagógica y Tecnológica de Colombia. Tunja, Colombia. carlosgabriel.hernandez@uptc.edu.co.

2. Ph. D. (c) Universidad Pedagógica y Tecnológica de Colombia. Tunja, Colombia. jorge.sarmiento02@uptc.edu.co.

3. M. Sc. Universidad Pedagógica y Tecnológica de Colombia. Tunja, Colombia. juansebastian.gonzalez@uptc.edu.co. 
Keywords: housing; indicator; management; market; project.

\section{Resumen}

El mercado mundial se encuentra inmerso en un entorno de incertidumbre económica y política, donde el comercio y la producción industrial muestran signos de marcada debilidad. Sin embargo, en países en vías de desarrollo como Colombia, existe una expectativa de crecimiento económico moderado, atribuido a la implementación de estrategias orientadas a la creación de empleo, construcción de infraestructura pública y servicios para satisfacer las necesidades de su población en rápida expansión y urbanización. En consecuencia, esta investigación analiza los fenómenos externos que han impactado la economía colombiana en el comportamiento de la oferta y demanda de vivienda del sector de la construcción. Todo lo anterior, a través del análisis de indicadores económicos, políticas públicas y gestión de actores en torno al uso de herramientas, enfoques y metodologías establecidas por diferentes estándares en la gestión de proyectos junto con el análisis de una muestra empresarial ubicada en la ciudad de Tunja. Como se mencionó anteriormente, permitió establecer la susceptibilidad de los fenómenos económicos externos y las políticas gubernamentales en el sector de la construcción. Estas permitirían aumentar la demanda e impulsar otras áreas de la economía por efecto de los actores de la oferta y las capacidades empresariales en cuanto a su gestión, reconociendo las expectativas en la formulación y elaboración de proyectos en el contexto actual. Sin embargo, las empresas relacionadas con el sector de la construcción no cuentan con las herramientas ni con el personal adecuado para este desarrollo integral, lo que permite identificar los factores a la hora de evaluar las capacidades empresariales en torno a la gestión de los grupos de interés, contribuyendo a generar nuevas metodologías e instrumentos que permitan incrementar el éxito en los proyectos de construcción.

Palabras clave: gestión; indicador; mercado; proyecto; vivienda.

\section{Resumo}

O mercado mundial está imerso em um ambiente de incerteza econômica e política, onde o comércio e a produção industrial mostram sinais de fraqueza acentuada. No entanto, em países em desenvolvimento como a Colômbia, existe uma expectativa de crescimento econômico moderado, atribuído à implementação de estratégias voltadas para a criação de empregos, construção de infraestrutura e serviços públicos para atender às necessidades de sua população em rápida expansão e urbanização. Consequentemente, esta pesquisa analisa os fenômenos externos que têm impactado a economia colombiana no comportamento da oferta e demanda habitacional no setor da construção. Tudo isso, através da análise de indicadores econômicos, políticas públicas e gestão de atores em torno do uso de ferramentas, abordagens e metodologias estabelecidas por diferentes padrões de gestão de projetos em conjunto com a análise de uma amostra de negócios localizada na cidade de Tunja. Conforme mencionado acima, permitiu estabelecer a suscetibilidade de fenômenos econômicos externos e políticas governamentais no setor da construção. Estas permitiriam aumentar a procura e dinamizar outras áreas da economia a partir dos actores da oferta e das capacidades empresariais ao nível da sua gestão, reconhecendo as expectativas na formulação e elaboração de projectos no contexto actual. No entanto, as empresas ligadas ao setor da construção não dispõem de ferramentas nem de pessoal adequado para este desenvolvimento integral, o que permite identificar os fatores na avaliação da capacidade empresarial em torno da gestão de grupos de interesse, ajudando a gerar novas metodologias e instrumentos que permitem aumentar o sucesso dos projetos de construção.

Palavras-chaves: gestão; habitação; indicador; mercado; projeto.

\section{Introduction}

The global market immersed in environments of economic and political uncertainty, volatility, and reduced commercial growth, where the intensification of trade tensions among with a slowdown in global investment and a decline in confidence 
continue beyond the forecasts(International Monetary Fund, 2019b), (World Bank Group, 2019a). These tighter financial conditions and the weakening of fiscal stimulus are the main drivers of the slowdown in economic growth, with trade and manufacturing showing signs of marked weakness (World Bank Group, 2019a). Consequently, the fall in industrial production, especially capital goods, was widespread. However, accentuated in the advanced economies except for the United States. Variations are also related to the loss of optimism in the markets caused by trade tensions related to inefficiencies in public spending. Nevertheless, economic growth expects to be moderate in developing countries like Latin America, slowly approaching $+2 \%$ and stabilizing at $5 \%$ on average (International Monetary Fund (IMF), 2019b).

Part of this sustained growth indicates early signs of recovery due to the payment of public expenditure arrears, which allows for an increase in investment capacity to cushion housing loans and boost economies based on the extraction of raw materials. The construction and trade sectors have predicted that contributing to one percentage point to GDP is expected to grow at about 3,9 percent per annum until 2030 (World Bank Group, 2019b). Therefore the (International Monetary Fund (IMF), 2019a) predicts that low-income developing countries and some emerging market economies will need to create jobs and improve public infrastructure as services to meet the needs of their rapidly expanding and urbanizing populations. These suggestions were implemented in conjunction with the labour muscle provided by the construction sector. Where over the last decade, most of the growth came from emerging markets, while developed markets have not fully recovered their pre-crisis volumes (Asociación Nacional de Empresarios de Colombia (ANDI), 2019), (Hatzius et al., 2018).

Consequently, the construction sector allows the improvement of citizens' quality of life by producing new or renovated infrastructure. However, its scope is limited by the value of sufficient demand, determined by the number of fixed assets. Part of capital is allocated by the public sector like an investment, according to its social functions supported by the private sector. Therefore, state investments will restrict the amount and type of civil works carried out; accordingly, the anticipation and knowledge of the external or internal effects on the economy and the sector will clarify their social development impact. However, the complexity of variables about problems and needs of their collective approach, where methods are applied to support solutions, recognized and accepted by the stakeholders. Based on the assessment of identifiable patterns and phenomena that are understood, determines the degrees of opportunity that will allow adaptation to changes in the future (Velásquez y Sepúlveda, 2015), (Kamenetskii, 2013). Nevertheless, delays in schedules, cost overruns, and shortfalls to stakeholder expectations are recurrent. Affecting negatively and excessing the cost; this is related to technical inefficiencies, the combination of work methodologies and transfers to provide services to stakeholders, where differences between the estimated and the caused in the project are between $28 \%$ and $30 \%$ more in a larger public construction project in the world (Ellis $y$ Mice, 2019).

These suggestions implemented, in conjunction with the labor muscle, provided by construction and tangible products translated as the quality of life where the last decade, most of the growth came from markets in emerging countries (Asociación Nacional de Empresarios de Colombia (ANDI), 2019), (Hatzius et al., 2018). Based on the above, this research evaluated the economic impact on the construction sector, the performance of the housing sub-sector in Colombia, and public policies concerning capacities, tools, and stakeholder management by describing the organizations and perceptions of managers in housing construction projects in the city of Tunja in the Republic of Colombia, identifying the capacities, tools, and management of stakeholders to project management criteria. 


\section{Methodology}

The demand for housing in the country and the city of Tunja was examined to identify and analyze stakeholder management's impact in construction projects. These to establish the overall effects of the economy and government policies through information provided by the National Administrative Department of Statistics (DANE) and the National Planning Department (DNP); In parallel, the business characterization will be through the database of legally constituted companies provided by the Tunja Chamber of Commerce and the Colombian Chamber of Construction (CAMACOL), the latter as institutions in charge of exercising a public auction in the commercial register of all companies and the construction sector respectively. Through descriptive statistical treatments, in summary, figure 1 presents the methodology used.

Jointly, a business sample dedicated to housing construction in the city of Tunja was evaluated employing a random selection and, subsequently, evaluating the business capacity and perceptions of stakeholders' instruments and management. The variables selected were established through the research process to characterize the construction sector in the city of Tunja (Sarmiento-rojas, Medina Suárez, y Gutiérrez-junco, 2018), and the information obtained is ordered using descriptive statistical treatments.

\section{Results and discussions}

\section{Analysis of the study area}

The study area corresponds to the city of Tunja, the capital of Boyacá, located in Colombia. It has $121.4 \mathrm{~km}^{2}$ divided into rural and urban, concentrating in the last $92 \%$ of the population. It was evaluated by the community and housing census of 2018 by the DANE; it estimated 202.996 inhabitants in 2020. The population ages are reduced by less than ten years, an increase in the population over 40 years, and a concentration of the majority population between an age range of 18 and 30 years, who expects to drive the growing demand for housing. However, this growth may be relatively modest, given this population's particular characteristics (Green y Lee, 2016).

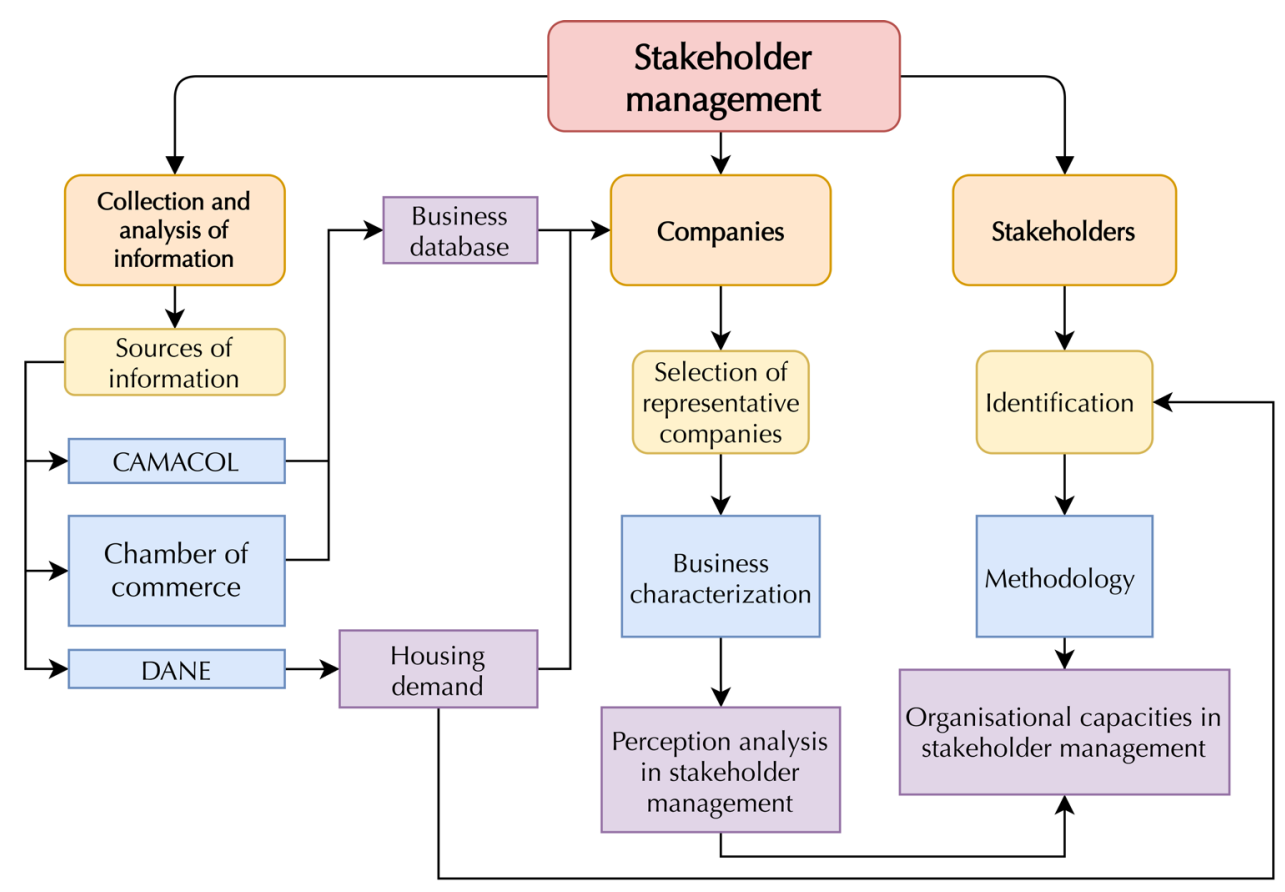

Figure 1: Diagram of the working methodology used 


\section{Analysis of the demand in housing construction.}

\section{National analysis of demand in housing construction}

The adequate performance of the building construction sector is associated with the promotion of economic and social development, thanks to the capacity to generate employment, to the input of demand from other industrial sectors and to the construction of housing that improves the quality of life of citizens as a central activity in the social and economic development of the country, especially in countries such as Colombia, where there is a considerable housing deficit and it is common to generate policies that include budgetary allocations directly or through financial institutions (Córdova y Alberto, 2018), considering the economic exploitation by organizations; However, they should focus their efforts on the development and subsequent implementation of projects that involve the pressing needs of stakeholders (Project Management Institute, 2017), where the reduction inbuilt area is consistent with the decline in demand for housing in the country, especially in those that do not receive state subsidies $(\mathrm{No} \mathrm{SIH})$ by $15 \%$ since 2016 , which has dominated the market, reaching a share of $75 \%$ as shown in figure 2 . The demand for non-SIH housing above $350 \mathrm{NMW}$ and in the range of 136-350 NMW (National Minimum Wage, equivalent to US\$230) has decreased by $62 \%$ and $72 \%$, respectively. However, the construction of Social Interest Housing $(\mathrm{SIH})$ has grown by $55 \%$ in a price range of 111-135 NMW, and building permits for $\mathrm{SIH}$ reached an increase of 2,055,176 $\mathrm{m}^{2}$, the highest growth in the last ten years. However, in SIH housing, with a price range between 91-110 NMW, its reduction has reached $50 \%$. In the same way, with Priority Interest Housing (PIH), characterized by Law 1955 of 2019 with values below $90 \mathrm{NMW}$ have reduced their market share in a range of $32 \%$ to $48 \%$ as a result of policies that seek to encourage supply in housing construction through Law 1607 of 2012. In this law, construction companies refund or compensate the Value Added Tax (VAT) paid to acquire materials to construct social and priority housing. Thus, generating market approaches in projects where companies and stakeholders find a higher remuneration of income and subsidy respectively by the State with the formulation and implementation of projects according to current market capacity.

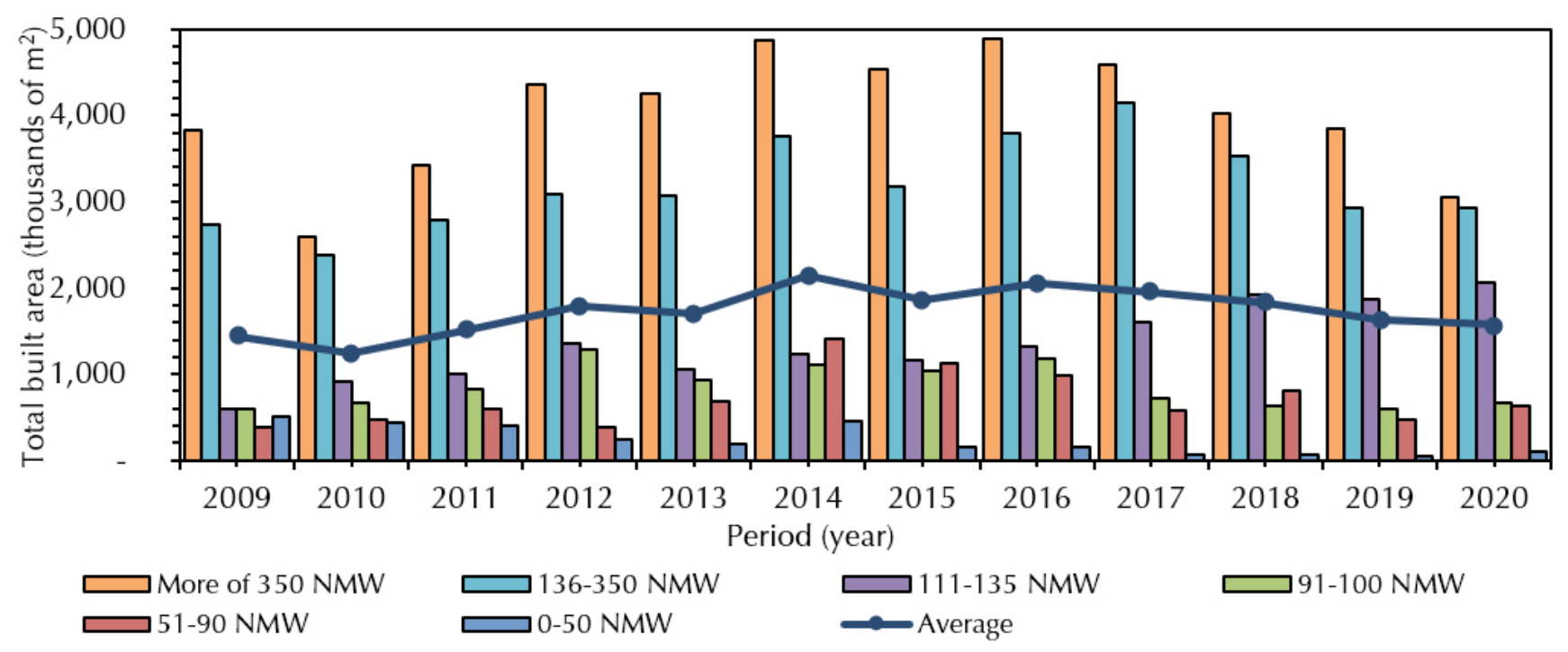

Figure 2: Housing demand-built area discriminated by price range Source: Own elaboration with information of DANE. 
The slowdown caused by macroeconomic events directly affects the housing market. It has particular characteristics that differentiate it from most investment assets, considered a mixed good that can be consumed and provide service flows for occupation and investment as a social purpose of the State and its preservation over time-considering that these markets adjust through slow processes that involve considerable transaction costs in terms of search and negotiation (Duran Vanegas, 2016), (Glaeser y Nathanson, 2014), (Glaeser y Nathanson, 2014). Besides, housing concentrates most of the wealth of households. It has an essential impact on the growth of a large number of economies, and the performance of its market is strongly linked to economic cycles. Therefore, the reduction of unsubsidized housing implicitly exposes the influence of investment demand on the market and its effect on the economy's financial stability.

Consequently, the reduction in demand for housing impacts global production in the construction sector. Public investment mitigated the decline in houses by investing in social housing $(\mathrm{SIH})$, differentiating the stakeholder approach to project formulation, which could be sustained and focused on SIH. Notwithstanding, despite the State investment, a decrease recorded in the area caused in housing construction that explains almost in its entirety the behavior of the construction segment, presenting an annual reduction of $16.3 \%$, where the demand in non-SIG housing causes $11 \%$, that contrasts with the $12.5 \%$ growth in civil works (Investigaciones Económicas Corficolombiana, 2019). Notwithstanding, it stated that the Colombian economy's growth rate is positively related to public expense in human capital and physical infrastructure (Ortiz et al., 2019).

Analysis of demand for construction in the city of Tunja

The demand for housing in Tunja has reduced due to the macroeconomic effects, as it has the national territory. It was fluctuating according to the latest period of economic slowdown (Cámara Colombiana de la Construcción (CAMACOL), 2019). The phenomenon showed in Figure 3 . The inbuilt reduction area since 2017 has been 57\%, a gradual and almost constant decrease of approximately $57,000 \mathrm{~m}^{2}$ per year, consistent with the decline in housing demand.

The University of Zilina, The Faculty of Operation and Economics of Transport and Communication,

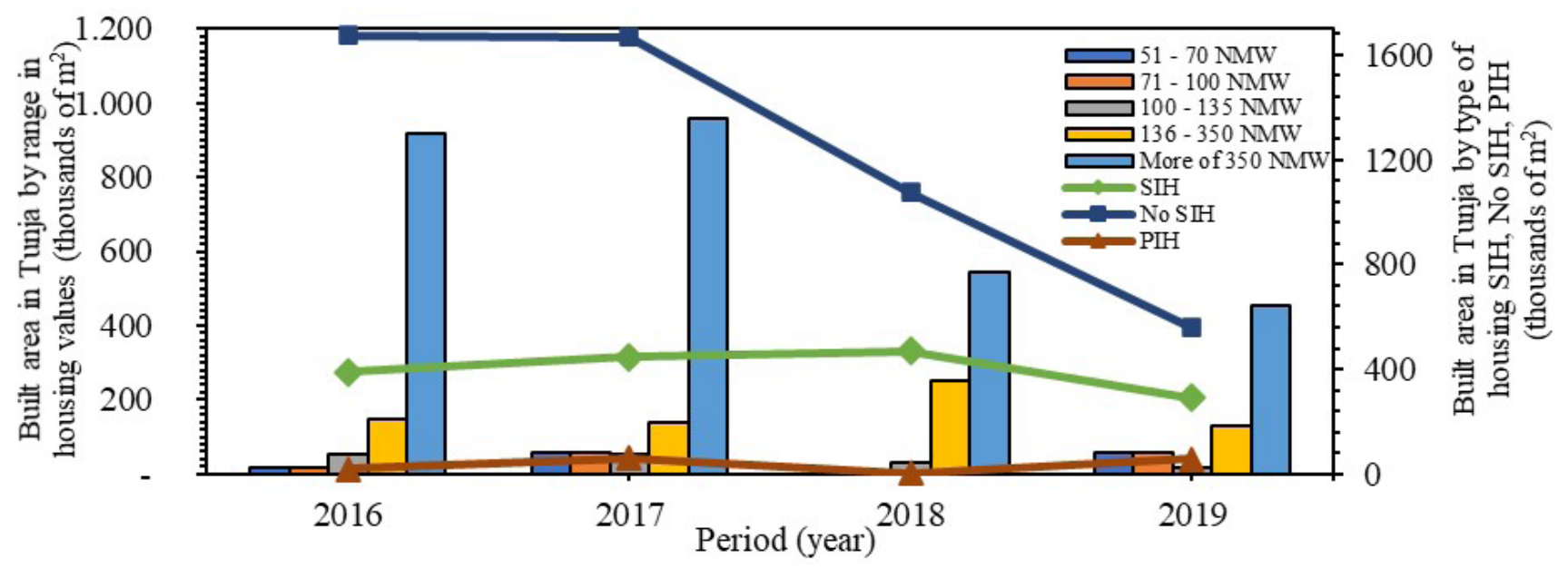

Figure 3: Temporary analysis of the demand for housing construction in the city of Tunja Source: Own elaboration with information of DANE. 


\section{Obtention and evaluation of business sample}

Based on the number of companies related to the construction sector registered with the Chamber of Commerce of the city of Tunja corresponding to 202 companies $(N)$ in the year 2018, using a confidence level of $95 \%(p)$ and a marginal error of $5 \%$ ( $q$ and $e$ ), the sample size calculated according to the equation (1).

$$
n=\frac{N \cdot Z_{\alpha}^{2} \cdot p \cdot q}{e^{2} \cdot(N-1)+Z_{\alpha}^{2} \cdot p \cdot q}
$$

The result of the necessary representative sample with $96 \%$ confidence corresponds to $36 \mathrm{com}$ panies, chosen at random with the requirement to participate in at least one housing construction project. The selected companies were then classified based on Law 905 of 2004, which establishes the size of the company according to the number of employees ( $n$ ) and assets (A) in the current national minimum wage (SMN). Based on the above, the result of the necessary representative sample with $96 \%$ confidence corresponds to 36 companies, chosen at random with the requirement to participate in at least one housing construction project. The selected companies were then classified based on Law 905 of 2004, which establishes the size of the company according to the number of employees (n) and assets (A) in the current national minimum wage $(\mathrm{SMN})$. Figure 4 shows the percentage distribution of the sample of selected companies classified by size, where this classification by company is congruent with the Colombian business fabric, which is mostly of small and medium-sized companies, which represent 99.5\% of the national business park (Franco Ángel, 2019).

In the business characterization, small and medium-sized companies represent $83.4 \%$ of the companies analyzed in this research. Therefore, the role they play in this sector compared with the dynamics of other actors in the Colombian economy, which are critical to the development of the Colombian economy and are considered the mainstay of modern economics, is vital to sustaining economic growth in the long term. This stimulates and stabilizes in times of recession, such as the one currently hitting the construction sector (Ardic, Mylenko, y Saltane, 2011), (Franco Ángel, 2019), (Varum y Rocha, 2013). This type of company has a flat structure, with less bureaucracy, procedures, and formal systems, facilitating rapid decision-making and responsiveness to the market

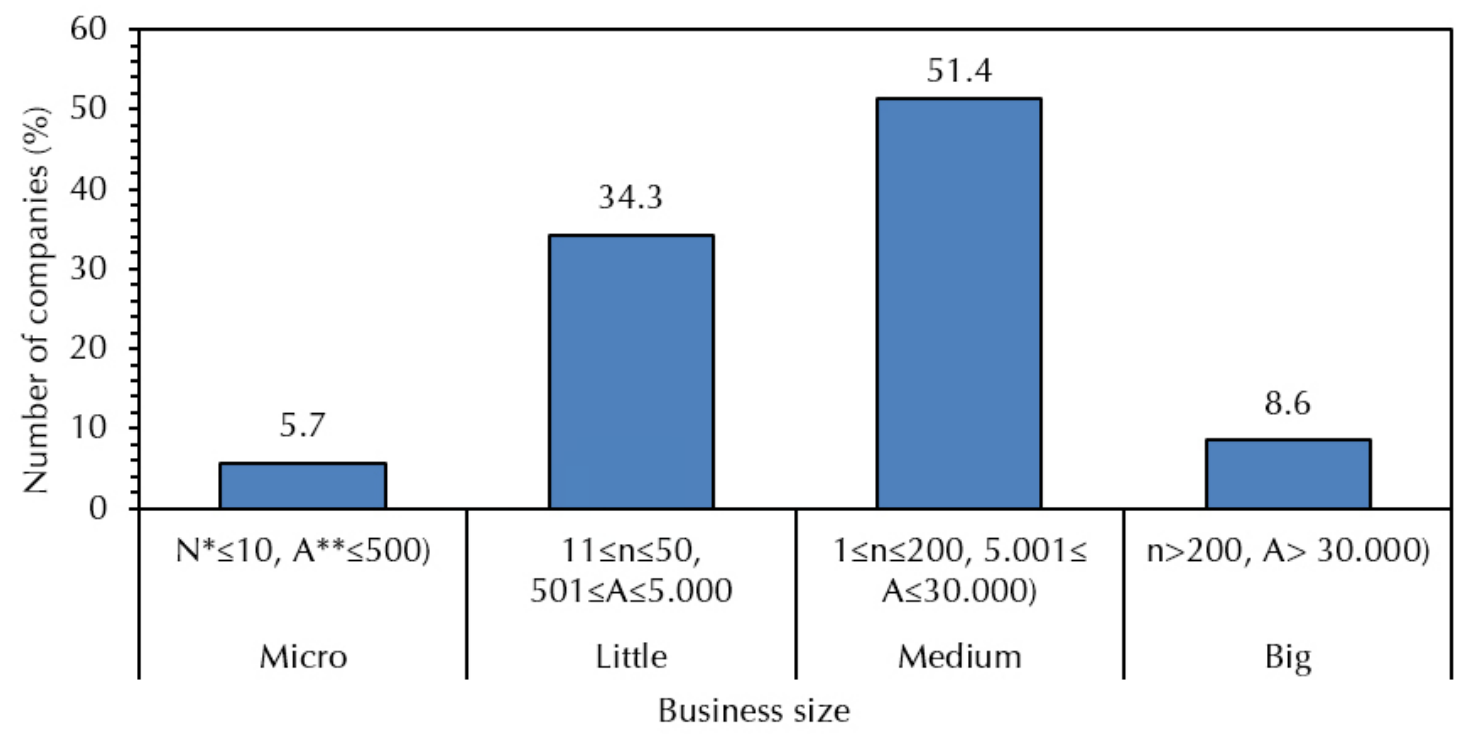

Figure 4: Business classification by size. 
(Usama, Fauziah, y Yusoff, 2018). However, these companies have weaknesses intrinsic to their size and scope. Principally due to the restricted management of capital, this reduces their competitiveness and limits their growth. This issue translates into limited access to financing sources, to new and more considerable resources and management capabilities; consequently, this type of company lacks many management skills in employees and stakeholders (Franco Ángel, 2019).

\section{Management capacities of the organizations}

Construction projects' complex and unstable nature requires systematic approaches and appropriate project managers' skills to get the best value from project outcomes. These include stakeholders, considering a practical approach identifying needs and developing mutual relationships with the project, understanding the "invisible power" of stakeholders about organizational strategies to meet harmoniously with stakeholders (Srinivasan y Dhivya, 2019), (Mok, Shen, y Yang, 2015). Consequently, when assessing the manager and the work team's quality, it will be possible to establish the performance in the management of the organization's stakeholders. Consequently, when assessing the previously characterized business sample's management capacities, $77.7 \%$ of the respondents are managers or owners of the organization, declaring $75 \%$ to have transparent staff selection methodologies. From them, 95\% of the companies have a specific area to centralize the planning, execution, follow-up, and closing of the projects, facilitating and optimizing the planning and execution processes.

\section{Management of organizations in collecting information}

The construction sector is one of the most information-dependent industries (Senaratne, Senaratne y Ruwanpura, 2016). Therefore, it is necessary to create management mechanisms with stakeholders to establish direct relationships with the organization; consequently, it is essential to address stakeholders' interests and welfare under the organization's objectives (Phillips, Freeman y Wicks, 2016). Therefore, the collection of information allows mitigating the risks involved in the high number of change controls in conjunction with empirical processes and communication (Arteaga Ceballos, Barrera Pineda y Chaparro Pedraza, 2013). Consequently, the organizations evaluated stated that they incorporated stakeholder information and project planning and initiation with investors in $94.4 \%$, with suppliers $83.3 \%$, with potential customers $97.2 \%$ and government agencies $(100 \%)$; the latter are mandatory following the provisions of the country's internal laws. Having information from stakeholders mitigates the risks associated with uncertainties and the ability to process the data to establish a systematization in the use of requirements during project formulation and implementation (Fewings y Henjewele, 2019), (Van Gunsteren, Binnekamp y de Graaf, 2011); in contrast to the increased uncertainty, there is a more significant potential for deviations in project timing, budgets, and scope (Joslin y Müller, 2015), (Project Management Institute, 2017).

\section{Tools for project management}

In the management of projects and organizations, it is necessary to adopt and implement methodologies that generate more outstanding dynamics between the areas of knowledge and the systematization of skills of tools and techniques to meet strategic objectives (Carvalho, 2014), (Pinzón y Remolina, 2017); consequently, the use of these tools was evaluated in the business sample, management and its combined use in project management as shown in Figure 5.

In the last decades, companies have increased the use of this type of tool and project management to improve competitiveness, control complexity, and reduce costs. Therefore, there is a 


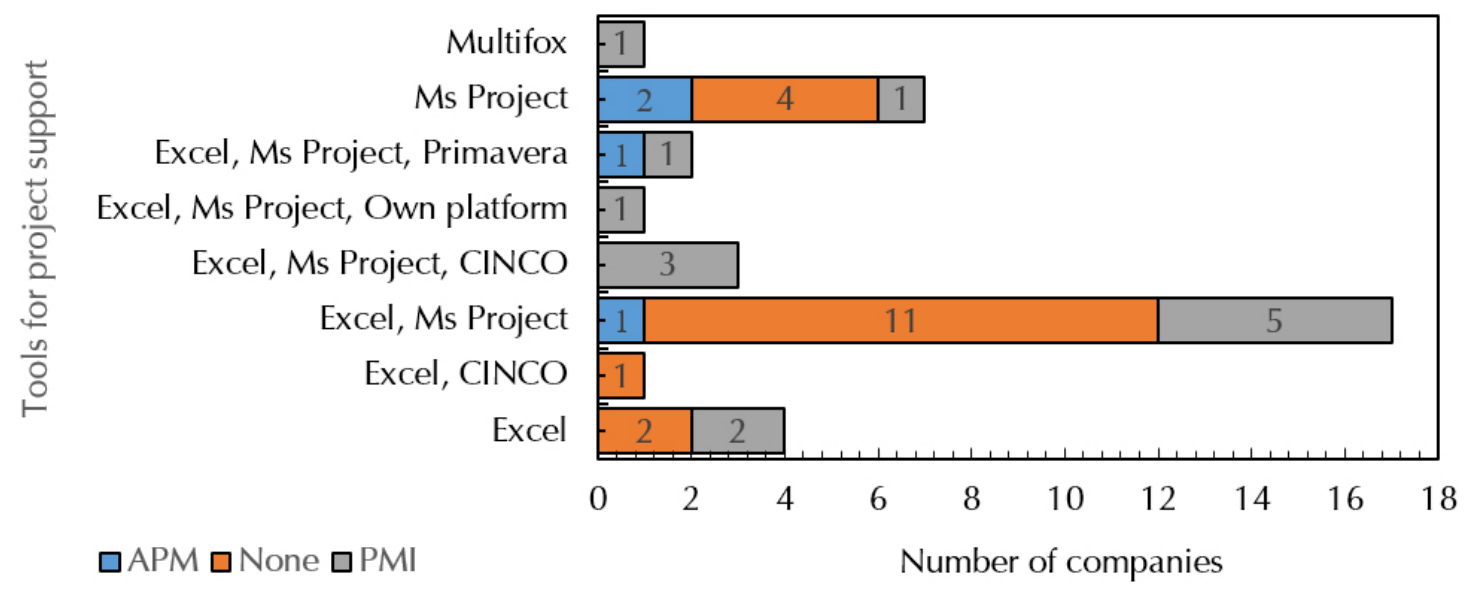

Figure 5. Business classification by size.

relationship between optimization in project management, the formulation of computer tools and standards to formalize methodologies, patterns, or models; some developed and disseminated by the Project Management Institute (PMI), Association for Project Management (APM), among others. The results express that half of the surveyed companies do not have processes or procedures aligned with any project management standard or methodology. 39\% use the guide PMBOK of the PMI and the minority with $11 \%$ with the standard APM. In conjunction, with the combination of technology platforms designed specifically for the follow-up and control of projects using combined generic software $(78 \%)$, like Microsoft Excel and Project, useful in projects of low complexity, related to the size and scope of the small and medium companies. However, some enormous range of tools, as Primavera, CINCO, Multifox, and Proprietary Platforms, are used by a small number of companies (22\%). A small number of organizations have database tools that collect and sort the documentation and information generated by projects (5\%).

\section{Socialization and communication of projects.}

Communication in the project generation is conceived as an exchange of information because it is a determining factor in the success of projects (Petter \& Nils, 2015). Therefore, poor communication encourages project failure and causes lower performance and more significant staff turnover, generating unnecessary costs and affecting the project's progress and quality. In essence, effective communication builds a bridge between the various stakeholders involved in a project, connecting cultural and organizational backgrounds, levels of expertise, and multiple perspectives and interests in the implementation or outcome (Project Management Institute, 2017), (Senaratne y Ruwanpura, 2016). Consequently, in the project's development, the progress and disposition of communication channels; the effectiveness in the transmission of information, and the mechanisms that allow the involvement and establishment gathering greater clarity the expectations of the stakeholders promote and reflect the performance and satisfaction that the organizations; as their stakeholders obtain from the execution of the projects (Jiang, Klein, Wu y Liang, 2009), (Sarmiento-rojas et al., 2018), (Tengan y Aigbavboa, 2017; Zafarani, 2011). Consequently, the result of evaluating this factor in the surveyed companies presented in Figure 6. The results show companies have difficulties in communication since $50 \%$ never socialize budgets with suppliers and contractors. Likewise, 33.3\% never socialize the budget with the work team and 
management, and $19.4 \%$ rarely socialize this type of document, preventing greater efficiency in the development of the work schedule and dynamic communication channels with contractors and suppliers that allow management processes carried out under the activities developed in the project, (Project Management Institute, 2016).

On the other hand, $91 \%$ of the companies carry out processes to socialize the schedule with the work team and the organization's management, and $59 \%$ with the project's suppliers and contractors; however, these tasks are mandatory and inherent to construction projects. The above exposes weaknesses in communication with stakeholders; in this, approaches address to identify the management relationships between team members, of this way, emphasizing mutual and harmonious cooperation of work between stakeholders and the contractor (Aichouni, Messaoudene, Al-Ghonamy y Touahmia, 2014), (Srinivasan y Dhivya, 2019). Due to the inherent influence on the implementation of construction projects and their expectations (Oppong, Chan y Dansoh, 2017), which allows establishing the success of the project as a complement to the traditional determinants (cost, quality, and time).

\section{Conclusion}

The construction sector, by its versatile, rapidly volatile nature and susceptible to external economic phenomena and a nation's internal policies, especially in countries like Colombia, is subtilized as an economic indicator. It also drives social development in times of crisis by constructing housing as a social purpose of the State, generating employment, and promoting other sectors of the economy. Consequently, by identifying and linking stakeholders in the face of some housing markets' restrictions and generational change, it makes it possible to formulate a differential approach to demand and supply, showing its effect on the housing market and affecting entrepreneurial capacities to its management. Therefore, stakeholders must be identified in the formulation and elaboration of projects by collecting information inherent to construction projects, which allows for clarity and precision with the project's objectives, promoting the execution of resources and higher value for the organization. However, the companies related to the construction sector in the city of Tunja do not have a set of tools and personnel suitable for the development and implementation

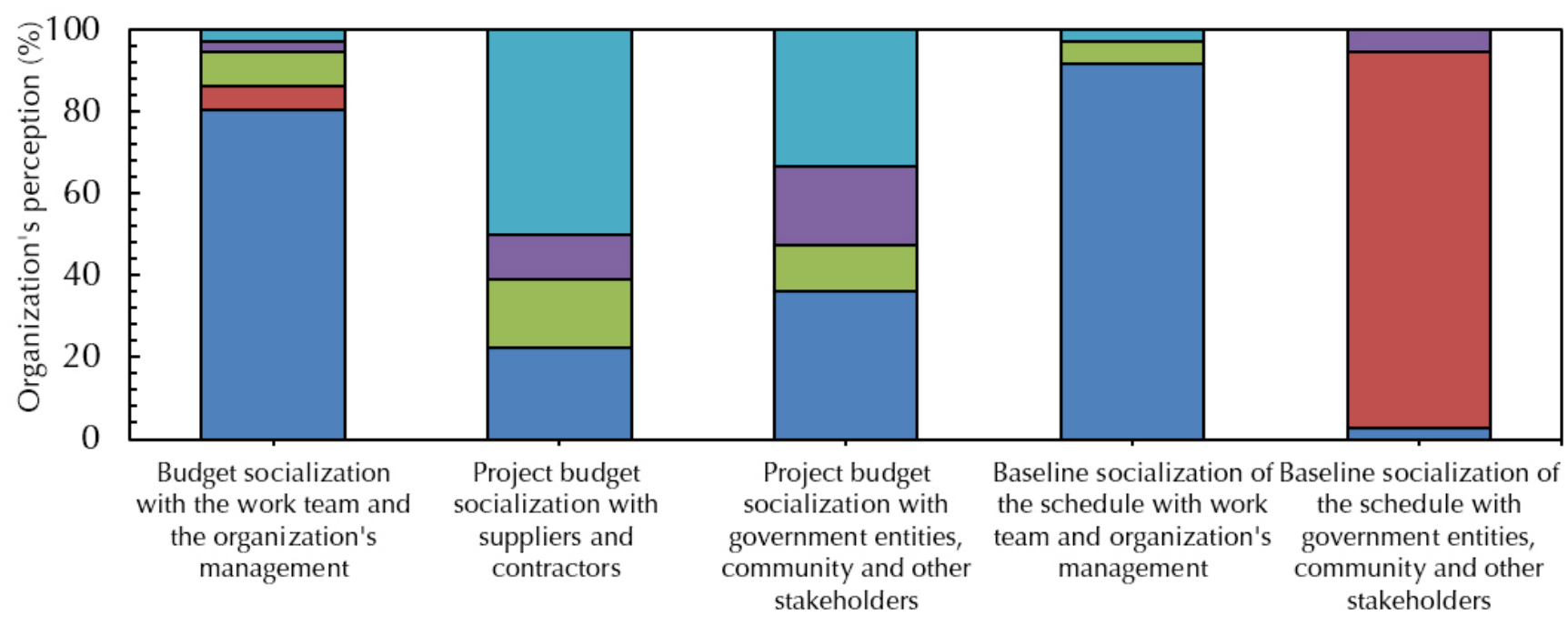

$\square$ Always $\quad \square$ Almost always $\quad \square$ Sometimes $\quad$ Rarely $\square$ Never

Figure 6: Socialization of projects with stakeholders. 
of differential treatment of stakeholders together with difficulties to systematize and develop skills and abilities needed in an environment increasingly limited, wild, uncertain and competitive. Consequently, identifying these factors allows the assessment of business capacities to provide adequate management concerning economic changes and demand, together with the capabilities of the construction sector.

\section{References}

Aichouni, M., Messaoudene, N., Al-Ghonamy, A., Touahmia, M. (2014). An empirical study of quality management systems in the Saudi construction industry. International Journal of Construction Management, 14(3), 181-190. https://doi.org/10.1080/ 15623599.2014 .922724

Ardic, O., Mylenko, N., Saltane, V. (2011). Small and Medium Enterprises A Cross-Country Analysis with a New Data Set. World Bank Policy Research, 5538, 1-31. https://doi.org/10.1596/1813-9450-5538

Arteaga Ceballos, C., Barrera Pineda, F., Chaparro Pedraza, J. J. (2013). Factores claves para la gestión de proyectos tecnológicos. TIA, 2(1), 117-137.

Asociación Nacional de Empresarios de Colombia (ANDI). (2019). Colombia: Balance 2018 y Perspectivas 2019. Bogotá, Colombia: ANDI.

Carvalho, M. M. (2014). An investigation of the role of communication in IT projects. International Journal of Operations and Production Management, 34, 36-64.

Cámara Colombiana de la Construcción (CAMACOL). (2019). Oferta de vivienda nueva: Fundamentales macroeconómicos y perspectivas. Estudios Económicos, 105, 1-14.

Córdova, J., Alberto, C. (2018). Medición de la eficiencia en la industria de la construcción y su relación con el capital de trabajo. Revista Ingeniería de Construccion, 33(1), 69-82. https://doi.org/10.4067/ s0718-50732018000100069

Duran Vanegas, J. (2016). El Efecto del Endeudamiento Hipotecario sobre los Precios de Vivienda en Colombia. Coyuntura Económica, 46(2), 41-75.
Ellis, L., Mice, C. (2019). Factors influencing triple constraints in public sector projects in Trinidad and Tobago. Ice Publishing, 172, 157-169.

Fewings, P., Henjewele, C. (2019). Construction Project Management Construction. (Third Edit). New York: Taylor \& Francis Group.

Franco Ángel, M. (2019). Caracterización de las pymes colombianas y de sus fundadores: un análisis desde dos regiones del país. Estudios Gerenciales, 35(150), 81-91. https://doi.org/10.18046/j. estger.2019.150.2968

Glaeser, E., Nathanson, C. (2014). Housing Bubbles. National Bureau of Economic Research, 5, 701-751.

Green, R. K., Lee, H. (2016). Age, demographics, and the demand for housing. Regional Science and Urban Economics, 61, 86-98. https://doi.org/10.1016/j. regsciurbeco.2016.09.005

Hatzius, J., Phillips, A., Mericle, D., Hill, S., Struyven, D., Chen, B., Choi, D., Taylor, B., Walker, R. (2018). The Home Stretch. Goldman Sachs, 1-15.

International Monetary Fund (IMF). (2019a). Fiscal Monitor, Curbing corruption. Washington, D.C, EEUU. International Monetary Fund (IMF).

International Monetary Fund (IMF). (2019b). World Economic Outlook, Weakening of global expansion. Davos, Switzerland.: International Monetary Fund (IMF).

Investigaciones Económicas Corficolombiana. (2019). Informe semanal, Rompiendo barreras. Bogotá D.C.: Corficolombiana

Jiang, J., Klein, G., Wu, S., Liang, T. (2009). The relation of requirements uncertainty and stakeholder perception gaps to project management performance. Jour. of Systems and Software, 82(5), 801-808. https://doi.org/10.1016/j.jss.2008.11.833

Joslin, R., Müller, R. (2015). Relationships between a project management methodology and project success in different project governance contexts. International Journal of Project Management, 33(6), 1377-1392. https://doi.org/10.1016/j. ijproman.2015.03.005

Kamenetskii, M. I. (2013). Construction sector as a factor of the prospective development of the national economy. Studies on Russian 
Economic Development, 24(3), 249-258. https:// doi.org/10.1134/S1075700713030052

Mok, K. Y., Shen, G. Q., Yang, J. (2015). Stakeholder management studies in mega construction projects: A review and future directions. International Journal of Project Management, 33(2), 446-457. https:// doi.org/10.1016/j.ijproman.2014.08.007

Oppong, G. D., Chan, A. P. C., Dansoh, A. (2017). A review of stakeholder management performance attributes in construction projects. International Journal of Project Management, 35(6), 1037-1051. https://doi.org/10.1016/j.ijproman.2017.04.015

Ortiz, C., Jiménez, D., Cruz, G. (2019). El impacto de la infraestructura en el crecimiento económico colombiano: un enfoque smithiano. Lecturas de Economía, 90, 97-126. https://doi.org/10.17533/ udea.le.n90a04

Petter, H., Nils, K. (2015). Communication, dialogue, and project management. International Journal of Managing Projects in Business, 7(1), 133-143.

Pinzón, J. L., Remolina, A. (2017). Evaluación de herramientas para la gerencia de proyectos de construcción basados en los principios del PMI y la experiencia. Prospectiva, 15(2), 51-59. https://doi. org/10.15665/rp.v15i2.746

Phillips, R., Freeman, R. E., Wicks, A. C. (2016). What Stakeholder Theory Is Not Author. Business Ethics Quarterly, 13(4), 479-502. https://doi.org/10.5840/ beq200313434

Project Management Institute (PMI). (2016). Construction Extension to the $\mathrm{PMBOK}^{\circledR}$ Guide, Pennsylvania. EE.UU.: PMI.

Project Management Institute. (2017). Guía del PMBOK. Pensilvania. EE.UU.: PMI.

Sarmiento-rojas, J. A., Medina Suárez, M. N., Gutiérrezjunco, Ó. J. (2018). Caracterización de la gerencia de proyectos de construcción en la ciudad de Tunja. Tunja. Editorial UPTC.
Senaratne, S., Ruwanpura, M. (2016). Communication in construction: a management perspective through case studies in Sri Lanka. Architectural Engineering and Design Management, 12(1), 3-18. https://doi. org/10.1080/17452007.2015.1056721

Srinivasan, N. P., Dhivya, S. (2019). An empirical study on stakeholder management in construction projects. Materials Today: Proceedings, 21(1), 60-62. https://doi.org/10.1016/j.matpr.2019.05.361

Tengan, C., Aigbavboa, C. (2017). Level of Stakeholder Engagement and Participation in Monitoring and Evaluation of Construction Projects in Ghana. Procedia Engineering, 196, 630-637. https://doi. org/10.1016/j.proeng.2017.08.051

Usama, M. K., Fauziah, W., Yusoff, W. (2018). The Relationship Between Entrepreneurs' Financial Literacy and Business Performance Among Entrepreneurs of Bauchi State Nigeria. International Journal of Entrepreneurship and Business Innovation, 1(1), 15-26.

Van Gunsteren, L. (2011). Stakeholder-oriented Project Management. Delft: IOS Press.

Varum, C. A., Rocha, V. C. (2013). Employment and SMEs during crises. Small Business Economics, 40(1), 9-25. https://doi.org/10.1007/s11187-011-9343-6

Velásquez, A., Sepúlveda, T. L. (2015). Fundamentos de la prospectiva "la disciplina del cambio." Semestre Economico, 3(6), 153-160.

World Bank Group. (2019a). Global Economic Prospects, June 2019: Heightened Tensions, Subdued Investment. Washington D.C, EE.UU.: World Bank Group.

World Bank Group. (2019b). Lao PDR Economic Monitor, Maintaining economic stability. Washington D.C, EE.UU.: World Bank Group.

Zafarani, E. (2011). Project Quality Management Approaches: A Comparative Evaluation of International Standards. IPED 